\title{
Different agricultural practices specify bacterial community compositions in the soil rhizosphere and root zone
}

\author{
Yan Wang ${ }^{1}$, Guowei Chen ${ }^{2}$, Yifei Sun ${ }^{1}$, Kun Zhu ${ }^{1}$, Yan $\mathrm{Jin}^{3}$, Baoguo $\mathrm{Li}^{1}$, Gang Wang ${ }^{1, *}$ \\ 1 Department of Water \& Soil Sciences, China Agricultural University, Beijing 100193, China \\ 2 Department of Civil Engineering, Hefei University of Technology, Hefei 230009, China \\ 3 Department of Plant \& Soil Sciences, University of Delaware, Newark, DE 19716, USA
}

H I G H L I G H T S

- Bacterial diversity and community structure differed among agricultural practices.

- Crop rotation enhanced bacterial community succession in rhizosphere.

- Bacterial evenness in root zone was highest from no-tillage plot.

\section{ARTICLE INFO}

Article history:

Received May 2, 2020

Revised July 30, 2020

Accepted August 7, 2020

Keywords:

Next generation sequencing

Agro-practices

Bacterial community

Rhizosphere
GRAPHICAL ABSTRACT
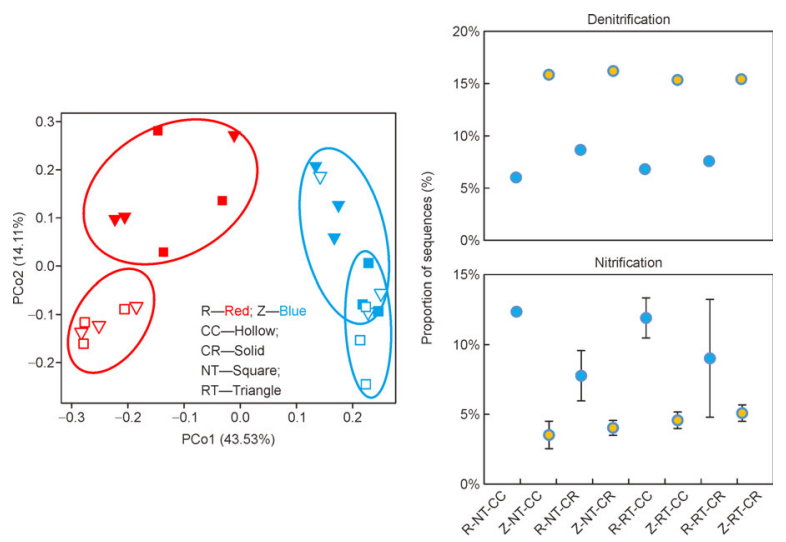

A B S T R A C T

We are only beginning to understand the influence of agricultural practices, together with soil properties and geographic factors, affect bacterial communities and their influence on the soil processes. Here, we quantify how typical agro-practices, i.e., no-tillage, ridge tillage, continuous corn cropping, and crop rotation with corn and bean, and the corresponding soil physicochemical characteristics affect bacterial diversity and community compositions of the rhizosphere and root zone soils. Results show that species richness in the rhizosphere was significantly higher than that in the root zone soils $(p<0.05)$, typically with more abundant Crenarchaeota and Firmicutes populations that are active members for $\mathrm{C}$ and $\mathrm{N}$ cycling. Specifically, crop rotation compared to other agro-practices was able to mediate soil $\mathrm{pH}$ value and the available $\mathrm{P}$ and thereby control the bacterial diversity pattern in the rhizosphere $(p<0.05)$, while tillage practices regulated the relative abundance of bacterial populations in root zone soils by varying the soil available $N(p<0.05)$. Analysis of biomarker patterns suggests that the observed differences in bacterial functional capabilities (e.g., nutrient cycling) are strongly related to the physicochemical properties of surrounding soils. Our results highlight the importance of soil-plant interaction in shaping soil bacterial community structure typically in the rhizosphere and root zone soils and also illustrates the challenges in linking soil ecosystem function to microbial processes.

(c) Higher Education Press 2020

\footnotetext{
* Corresponding author

E-mail address: gangwang@cau.edu.cn (G. Wang)
} 


\section{Introduction}

Soil microorganisms are often considered a key indicator for soil health and ecosystem stability (Avidano et al., 2005; Lin and $\mathrm{Hu}, 2008$; Hu et al., 2011; He et al., 2013), owing to microbial co-occurrence patterns and complex interactions that drive soil nutrients transformation and cycling (Tedersoo et al., 2014; Srivastava et al., 2016; James, 2019). However, agricultural management practices, in addition to natural factors, including tillage, cropping rotation, land use arrangement and fertilizer application, can significantly alter soil microbial diversity (Leff et al., 2015; Xu et al., 2018). Agricultural practices like tillage and crop rotation, as well as plant types, also influence soil microbial composition and community structure (Habig and Swanepoel, 2015; Miura, et al., 2016). Moreover, different plant statuses (e.g., diseased vs. disease-free) have striking effects on microbial community composition and structure even when sampled at the same location (Shanmugam et al., 2011). Intercropping has produced higher microbial richness diversity when compared to monocultures or simpler crop rotations (Venter et al., 2016). Conventional and conservational agricultural managements express significant difference in bacterial diversity (Herman et al., 1990; Miura, et al., 2016). This can be attributed to improved soil structure and the reduced destruction of macroaggregates by conservational agricultural practices, thus promoting soil organic matter (SOM) retention and maintaining the stability of soil microbial diversity and biomass (Mathew et al., 2012; Rincon-Florez et al., 2016). Despite progress made in recent years, studies on the effects of tillage and crop management on microbial biomass (Dogan et al., 2011; Hu et al., 2011; Huang et al., 2016), singular key-stone species (Albuquerque et al., 2006), and niche differentiation associated with the number of species (Zhang et al., 2001; Hooper et al., 2005) are lacking. Thus, more systematic and mechanistic investigations are needed to improve our understanding of microbial response to multi-agricultural practices (Garbeva et al., 2004).

Rhizosphere, the unique zone in vicinity of plant roots (Bais et al., 2006; Albuquerque et al., 2006), is the most active region where the interactions of root and soil microbes take place. Microbial activity in the rhizosphere can respond swiftly to perturbations, particularly diverse agricultural practices (Habig and Swanepoel, 2015). Root exudation, tissue exfoliation, and soil organic matter serve as nutrient sources for soil microbial growth, thus may be beneficial to maintaining soil microbial diversity and activity (Langmeier et al., 2013). Moreover, rhizosphere microbial processes and associated bacterial physiological characters differ from one plant species to another due to the difference of its total N, total P and plant litter content (Zhang et., 2001; Zhang et al., 2010; Zhu, 2020). Hence, the microbial communities harbored in rhizosphere are more complex than root zone soils and remain poorly understood (Fan et al., 2017). In addition, bacterial life patterns in rhizosphere and root zone soils and their responses to long-term agricultural practices remain largely unknown. In this study, four typical agricultural practices, including no-tillage, ridge tillage, continuous corn cropping, and crop rotation with corn and bean were examined and compared, using an advanced gene sequencing method (Johansson et al., 2004; Tedersoo et al., 2014). We explored the diversity and functional patterns of bacteria in the rhizosphere and root zone soils, as well as the mechanisms of bacteria and soil-plant interactions.

\section{Materials and methods}

\subsection{Field experiment and soil sampling}

The field experiment had been established since 2011 at Siping, Jilin Province, China (124 $\left.26^{\prime} \mathrm{E}, 43^{\circ} 16^{\prime} \mathrm{N}\right)$. This site has a continental monsoonal climate with annual average temperature and precipitation of $6.5^{\circ} \mathrm{C}$ and $577 \mathrm{~mm}$, respectively. The soil texture of the plough layer $(0-20 \mathrm{~cm})$ is classified as silty clay loam, with clay, silt and sand contents of $23.9 \%, 45.2 \%$, and $30.9 \%$, respectively. At the beginning of the experiment, the soil had a $\mathrm{pH}$ value of 7.0 , and the organic matter content was $21.0 \mathrm{~g} \mathrm{~kg}^{-1}$ with $1.7 \mathrm{~g} \mathrm{~kg}^{-1}$ total $\mathrm{N}$, $60.4 \mathrm{mg} \mathrm{kg}^{-1}$ available $\mathrm{P}$ (Olsen-P) and $88.6 \mathrm{mg} \mathrm{kg}^{-1}$ available $\mathrm{K}\left(\mathrm{NH}_{4} \mathrm{OAc}\right.$ extractable). Four agriculture treatments (each with three replicates), namely no-tillage (NT), ridge tillage (RT), continuous corn cropping (CC) and crop rotation with corn and bean (CR), were set as a randomized block design (plot size of $21.6 \mathrm{~m} \times 63.0 \mathrm{~m}$ ). Rhizosphere $(\mathrm{R})$ and root zone (Z) soil samples were collected from each treatment in triplicates in October 2015 and analyzed. Few millimeters adhered at plant root is called rhizosphere soil, root zone soil is collected around plant stem within only $10 \mathrm{~cm}$ distance which is different from bulk soil. Ten corn or bean seedlings were labeled randomly, and the soil sample of root zone was taken at a depth of $5-15 \mathrm{~cm}$ with $10 \mathrm{~cm}$ radius away from plant. The soil was then transferred immediately into a $4^{\circ} \mathrm{C}$ thermal container after mixing. Prior to further analysis, the collected soil samples from the root zone were put through a 2-mm sieve. Rhizosphere soil samples were collected from the roots of plants. In brief, $\sim 30 \mathrm{~g}$ fresh roots were collected and then washed gently with $50.0 \mathrm{~mL}$ saline $(0.75 \%)$ in an aseptic sealing bag. The suspension was collected and centrifuged (Anting TDL-5-A, Shanghai, China) at $5000 \mathrm{~g}$ for $10 \mathrm{~min}$ to harvest soil samples (Teixeira et al., 2010). Both rhizosphere soil samples and root zone samples were then divided into two aliquots and stored at $-20^{\circ} \mathrm{C}$ for DNA extraction and physicochemical property analysis.

\subsection{Soil physicochemical analysis}

Soil samples were heated at $105^{\circ} \mathrm{C}$ in an oven (BGZ series II, Boxun, China) for $48 \mathrm{~h}$ to determine water content. Soil $\mathrm{pH}$ value (soil to water ratio of 1:2.5) was measured using a $\mathrm{pH}$ meter (UB-7, DENVER, America) (Pierre, 1925). Soil organic 
matter was determined by oxidizing organic matter with a potassium dichromate (Gautheyrou, 2006), and total $\mathrm{N}$ by using the Kjeldahl method (Bradstreet, 1954). Available nitrogen (AN) was determined using the continuous alkalihydrolyzed reduction diffusion method (Bao, 2000). The Olsen method $\left(0.5 \mathrm{~mol} \mathrm{~L}^{-1} \mathrm{NaHCO}_{3}\right)$ was used to quantify available $\mathrm{P}$. Additionally, available $\mathrm{K}$ was determined by flame spectrophotometry (FP640, Shanghai, China) after extracted with $\mathrm{NH}_{4} \mathrm{OAc}$.

\subsection{DNA extraction and sequencing}

A half gram soil sample was used for total DNA extraction using a Fast DNA SPIN Kit (MP Biomedicals LLC, Ohio, USA). The extracted DNA was stored at $-80^{\circ} \mathrm{C}$ for further analysis (Fig. S1A). Amplifications of the V4 and V5 hypervariable regions of $16 \mathrm{~S}$ rRNA genes were performed using the universal primer 515F (5'-GTGCCAGCMGCCGCGGTAA-3') with a 6-bp barcode unique to each sample and the reverse 909R primer (5'-CCCCGYCAATTCMTTTRAGT-3') (Lindemann et al., 2013; Prest et al., 2014). All PCR reactions contained a $2.0 \mu \mathrm{L} 50$-fold diluted DNA template, $13.0 \mu \mathrm{L}$ double distilled water, 25.0 $\mu \mathrm{L}$ Premix Taq DNA polymerase (TaKaRa Biotech, USA), and $5.0 \mu \mathrm{L}$ of each primer for a total volume of $50.0 \mu \mathrm{L}$. PCR reactions were performed on a VeritiTM 96 Thermal Cycler (ABI, Vernon, USA) under the following conditions: denaturation at $94^{\circ} \mathrm{C}$ for $5 \mathrm{~min}$ ( 1 cycle), 30 cycles denaturation at $94^{\circ} \mathrm{C}$ for $40 \mathrm{~s}$, primer annealing at $56^{\circ} \mathrm{C}$ for $60 \mathrm{~s}$, extension at $72^{\circ} \mathrm{C}$ for $60 \mathrm{~s}$, and a final extension period of $10 \mathrm{~min}$ at $72^{\circ} \mathrm{C}$. The PCR products were purified using E.Z.N.A Gel Extraction Kit (Omega Bio-tek) (Fig. S1B). The 16S rRNA gene sequencing was carried out on an Illumina Miseq platform (Illumina, Inc., San Diego, CA, USA) using a $2 \times 250$ paired-end sequencing protocol.

\subsection{Bioinformatics and statistical analysis}

Based on the Illumina MiSeq platform, sample reads were assembled and optimized using the QIIME 1.9.0 software platform on Bio-Linux 5 (adapter, barcode, primer clipping, chimera removing) with Python scripts. Operational taxonomic unit (OTUs) were picked and species annotated using de novo OTU picking protocol with a $97 \%$ similarity threshold (Fig S2). According to the OTU results, all samples were analyzed for a diversity with 500 reads per samples (100 iterations), including Ace, Chao1 (species richness; Chao, 1984), Simpson index (diversity; Hunter and Gaston, 1988), Pielou's evenness (Pielou, 1969) and observed species. $\beta$ diversity was used to evaluate differences in community composition and structure. Bray-Curtis distance matrixes were calculated and visualized by Principal Coordinate Analysis (PCoA) and Unweighted Pair-Group Method with Arithmetic Means (UPGMA). Phylogenetic trees and cluster analyses were performed based on the taxonomy assignment of OTUs. In addition, FAPROTAX was used to predict the functional profiling of microbial communities based on the normalized contig-based 16S rRNA OTU table annotated against the greengenes database (collapse_table.py, http:// www.zoology.ubc.ca/louca/FAPROTAX/lib/php/index.php? section $=$ Home) .

Multiple factor analysis was used for the significance test of a diversity and functional profiles among samples. Analysis of similarities (ANOSIM) was performed to determine the significant difference in $\beta$ diversity between different agricultural practices. RDA ordination based on taxonomy of OTUs with the envfit function of the Vegan v.2.5-3 package in $\mathrm{R}$ was used to investigate and visualize correlations among different soil physicochemical properties influencing bacterial communities at the phylum level. Linear discriminant analysis coupled with effect size (LEfSe), LDA score (log 10), was used for identifying the taxa differences among various systems at the genus or higher levels (Segata et al., 2011). The R package Vegan v.2.5-3 and ggplot2 v.3.1 were used for data analysis and plotting.

\section{Results and discussion}

\subsection{Significant changes of bacterial abundance in rhizosphere} and root zone

Four diversity measures, richness (observed OTUs), Chao1, inverted Simpson and evenness (ACE), were performed to evaluate the variation of bacterial richness and evenness (Fig. 1). The bacterial species richness and evenness showed clear differences between the rhizosphere and root zone soils. Specifically, the estimated species richness (observed OTUs), Chao1 and evenness (Ace) index in the rhizosphere soil were noticeably higher than those in the root zone one, which is consistent with reported studies by Bing et al. (2013). In terms of community richness, continuous cropping gave greater richness and Chao 1 than crop rotation treatment in the same rhizosphere, but no significant difference was found between no-tillage and ridge tillage scenarios. Results from the multiple-factor analysis (Table 1) indicate that tillage method and cropping system showed little effects on a diversity. However, species richness, Chao1, and evenness index were all significantly different when comparing soils from the rhizosphere and root zone $(p<0.01)$ from the same field plots.

Soil bacterial abundance, expressed at the phylum level, in the rhizosphere and root zone under various tillage practices and crop rotation conditions are shown in Fig. 2, while the results of multiple-factor analysis are listed at Table S1. The 9 most abundant taxa accounted for more than $96 \%$ of reads, and the remaining $(\sim 4 \%)$ were unknown. Proteobacteria, Actinobacteria, and Acidobacteria were dominant in both rhizosphere and root zone soils, with the average relative abundance of $37.5 \pm 4.4 \%, 18.1 \pm 4.8 \%$, and $15.1 \pm 2.3 \%$, respectively. The relative abundances of the most dominant phyla (Proteobacteria, Acidobacteria, Actinobacteria, Bacteroidetes, Chloroflexi, Planctomycetes, Firmicutes, and Gemmatimonadetes) in rhizosphere were significantly different 
A
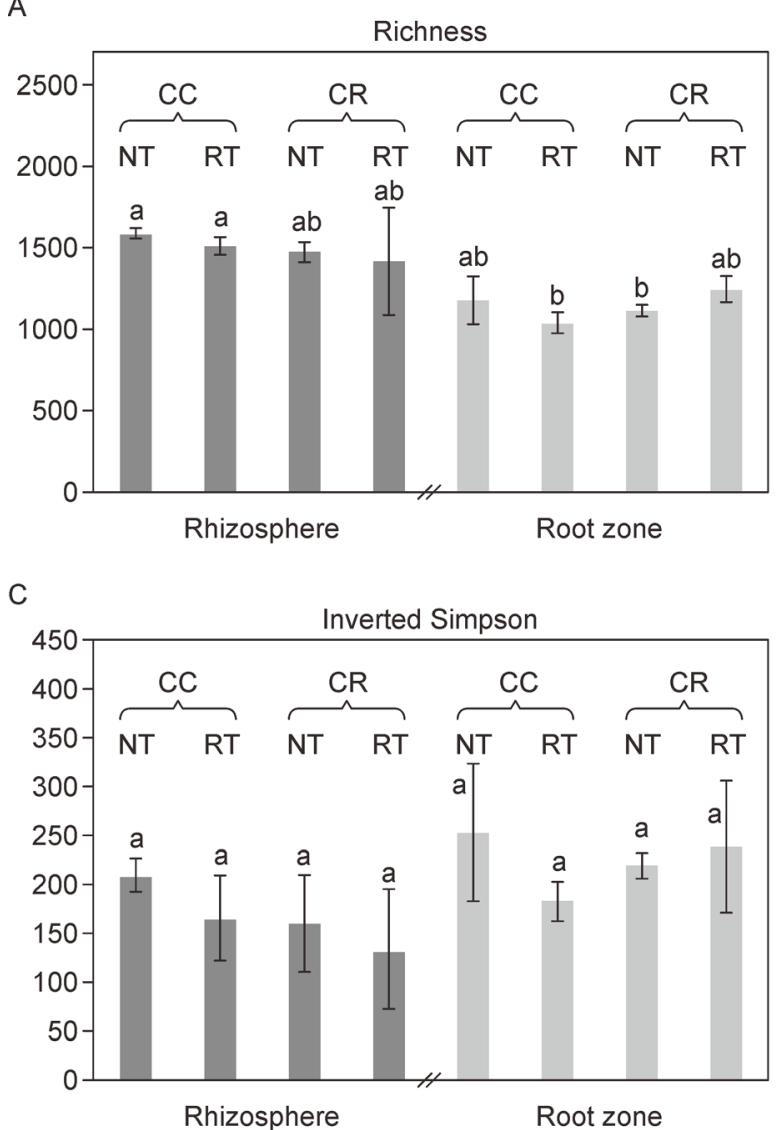

B

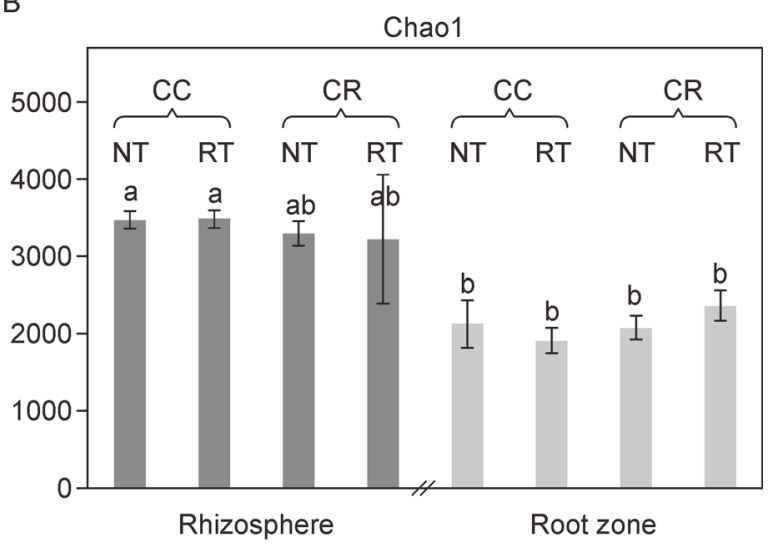

D

Evenness

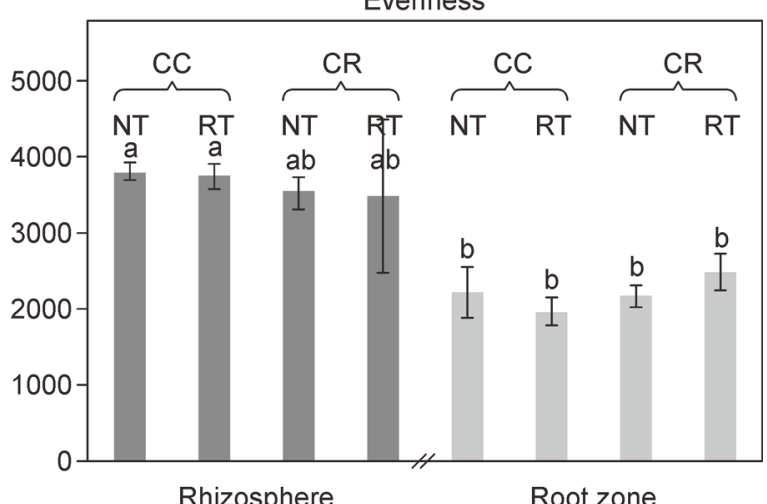

Fig. 1 The a diversity of each treatment. Dark gray is rhizosphere and light gray is root zone. (A) observed species represent richness of every treatment; $(B)$ and $(C)$ represent richness and evenness of every treatment, also, (D) represent evenness of every treatment. Note: Tillage methods contained no-tillage (NT) and ridge tillage (RT); Cropping rotation systems contained continuous cropping with corn (CC) and crop rotation with corn and bean (CR).

Table 1 Multiple factor analysis of a diversity with various agricultural practices in rhizosphere and root zone.

\begin{tabular}{|c|c|c|c|c|c|c|c|c|}
\hline \multirow[t]{2}{*}{ Factors } & \multicolumn{2}{|c|}{ Richness } & \multicolumn{2}{|l|}{ Chao1 } & \multicolumn{2}{|c|}{ Inverted Simpson } & \multicolumn{2}{|c|}{ Evenness } \\
\hline & $\mathrm{F}$ & $P$-value & $\mathrm{F}$ & $P$-value & $\mathrm{F}$ & $P$-value & $\mathrm{F}$ & $P$-value \\
\hline NT/RT & 0.89 & 0.36 & 1.73 & 0.21 & 0.00 & 1.00 & 1.33 & 0.27 \\
\hline $\mathrm{CC} / \mathrm{CR}$ & 2.04 & 0.17 & 2.05 & 0.17 & 0.06 & 0.81 & 2.11 & 0.17 \\
\hline $\mathrm{R} / \mathrm{Z}$ & 46.23 & $<0.01$ & 78.39 & $<0.01$ & 6.25 & $<0.05$ & 73.85 & $<0.01$ \\
\hline NT/RT-CC/CR & 0.06 & 0.81 & 0.15 & 0.70 & 0.10 & 0.75 & 0.07 & 0.79 \\
\hline NT/RT-R/Z & 4.60 & $\leq 0.05$ & 1.34 & 0.27 & 3.61 & 0.08 & 1.37 & 0.26 \\
\hline CC/CR-R/Z & 4.60 & $<0.05$ & 3.42 & 0.08 & 1.89 & 0.19 & 3.62 & 0.08 \\
\hline NT/RT-CC/CR-R/Z & 0.09 & 0.76 & 0.41 & 0.53 & 0.31 & 0.59 & 0.23 & 0.64 \\
\hline
\end{tabular}

Note: Tillage method, crop system, and location are three factors in our experiment. Tillage method: No-tillage (NT) or ridge tillage (RT). Crop system: continuous cropping with corn (CC) or crop rotation with corn and bean (CR). Location: Rhizosphere (R) or Root zone (Z). NT/RT, CC/CR, and $R / Z$ represent the extent of communalities and discrepancies of the individual data set caused by a single factor; NT/RT-CC/CR, NT/RT-R/Z, and $C C / C R-R / Z$ represent the extent of communalities and discrepancies of the individual data set caused by the interaction of two factors; NT/RT$\mathrm{CC} / \mathrm{CR}-\mathrm{R} / \mathrm{Z}$ represent the extent of communalities and discrepancies of the individual data set caused by the interaction of three factors. 


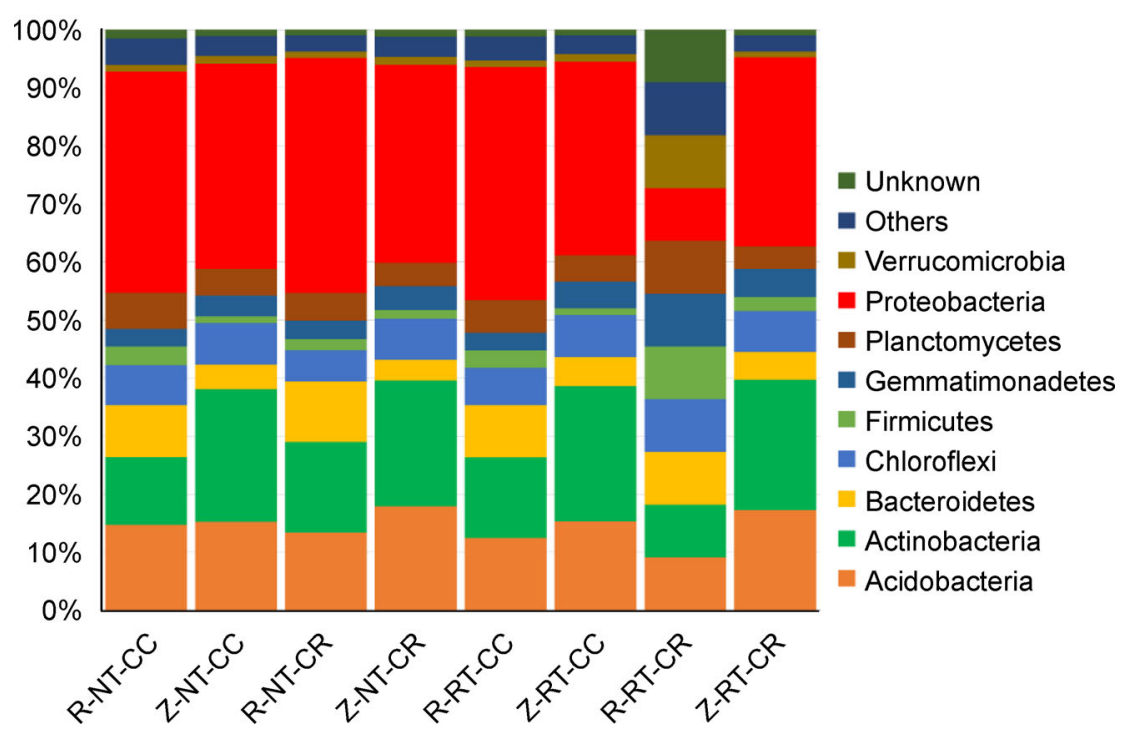

Fig. 2 Main bacterial composition of soil with agriculture practices. Each bar represents the average relative abundance of each bacterial taxon on phylum level. Tillage methods contained no-tillage (NT) and ridge tillage (RT), Cropping rotation systems contained continuous corn cropping (CC) and crop rotation with corn and bean (CR). The soil samples were collected from the rhizosphere $(\mathrm{R})$ and root zone $(\mathrm{Z})$ of five years typical continuous agricultural practices farmlands.

from those of root zone soils $(p<0.05)$. For example, the relative abundance of Proteobacteria at $35.4 \%-51.5 \%$ or Bacteroidetes at $0.8 \%-14.1 \%$ in rhizosphere were higher than $30.2 \%-36.4 \%$ and $2.9 \%-5.7 \%$ in root zone soils. However, Acidobacteria $(11.2 \%-16.3 \%)$ and Actinobacteria $(10.8 \%-17.8 \%)$ in rhizosphere were lower than $14.0 \%-19.7 \%$ and $20.7 \%-27.3 \%$ in root zone soils. The higher species richness of Proteobacteria in the rhizosphere soils as compared with that of the root zone soils was likely due to the availability of ${ }^{13} \mathrm{C}$ but in wheat root (Zhang et al., 2011; Ai et al., 2015). Moreover, according to the database of microorganisms (https://microbewiki.kenyon.edu/index.php/ MicrobeWiki), many of the bacterial taxa we identified $(p<0.05)$ in rhizosphere are already recognized for their functional capabilities in nutrient cycling or metabolic processes (Glöckner et al., 2003; Signori et al., 2014; Sun et al., 2015). Similarly, Nicol and Christa (2006) reported that Crenarchaeota and Firmicutes were positively affected by organic matter and available phosphorus and Crenarchaeota might considerably challenge the accepted view of global nitrogen cycling. Lindsay et al. (2012) found that Crenarchaeota and Firmicutes were active members in $\mathrm{C}$ and $\mathrm{N}$ cycles in the subsurface environment of the Witwatersrand Basin.

\subsection{Soil bacterial community clustered by agricultural practices}

The variations of soil bacterial community structure were delineated using PCOA and UPGMA cluster based on unweighted and weighted Bray-Curtis distance matrix (Fig. 3A and 3B). The two-dimensional PCoA plot (Fig. 3A) shows that the first principal coordinate accounted for $43.5 \%$ of total variation and differentiated the populations in rhizosphere from those of root zone soils. The second principal coordinate $(14.1 \%$ of total variation) separated rhizosphere soil populations by different cropping systems (CC and CR), but overlap in some populations was observed between tillage method (NT and RT) among root zone soils. Analysis of similarities (ANOSIM) found significant differences in bacterial composition between rhizosphere and root zone soils (ANOSIM; Global $R=0.73, p=0.001$ ). In addition, there was a significant difference in community structure in rhizosphere soils between cropping systems (ANOSIM; Global $R=$ $0.38, p<0.05)$ and in root zone soils between tillage treatments (ANOSIM; Global $R=0.31, p<0.05$ ). The results indicate that crop rotation plays a major role in manipulating bacterial distribution in both the rhizosphere and root zone soils. In addition, the UPGMA (Fig. 3B) further verifies the significant differences in bacterial compositions as a result of varied agricultural practices. In the rhizosphere, plant type and therefore the root exudate and nodule bacterium, as reported by Nannipieri et al. (2008) and Dogan et al. (2011), have been shown to contribute to the functional taxa selection, community evolution, and feedbacks. Consistent with results from Liiri et al. (2012), no-tillage combined with residue application increased soil organic matter, which led to increased soil microbial activity.

3.3 Effects of agricultural practices on soil physicochemical properties

The measured physicochemical properties of rhizosphere 
A

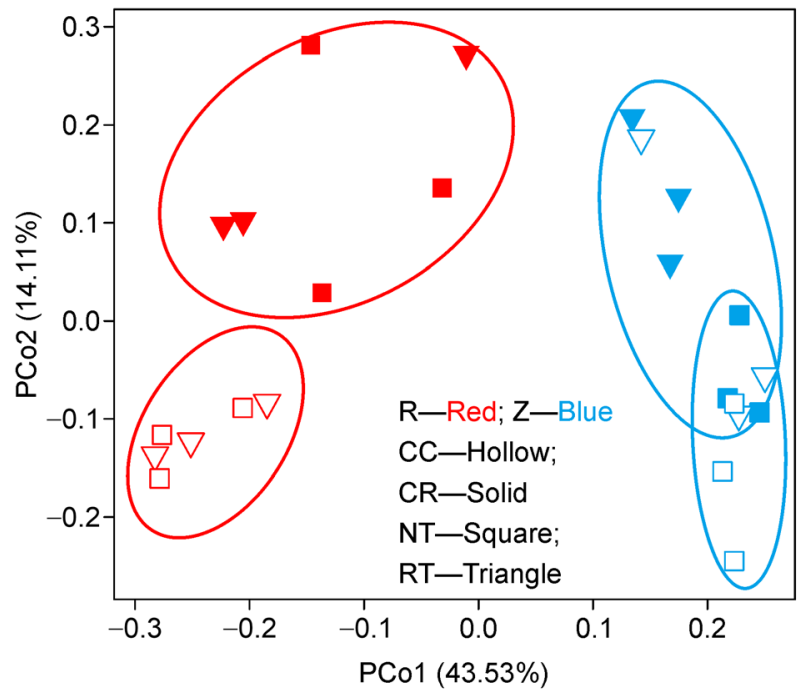

B

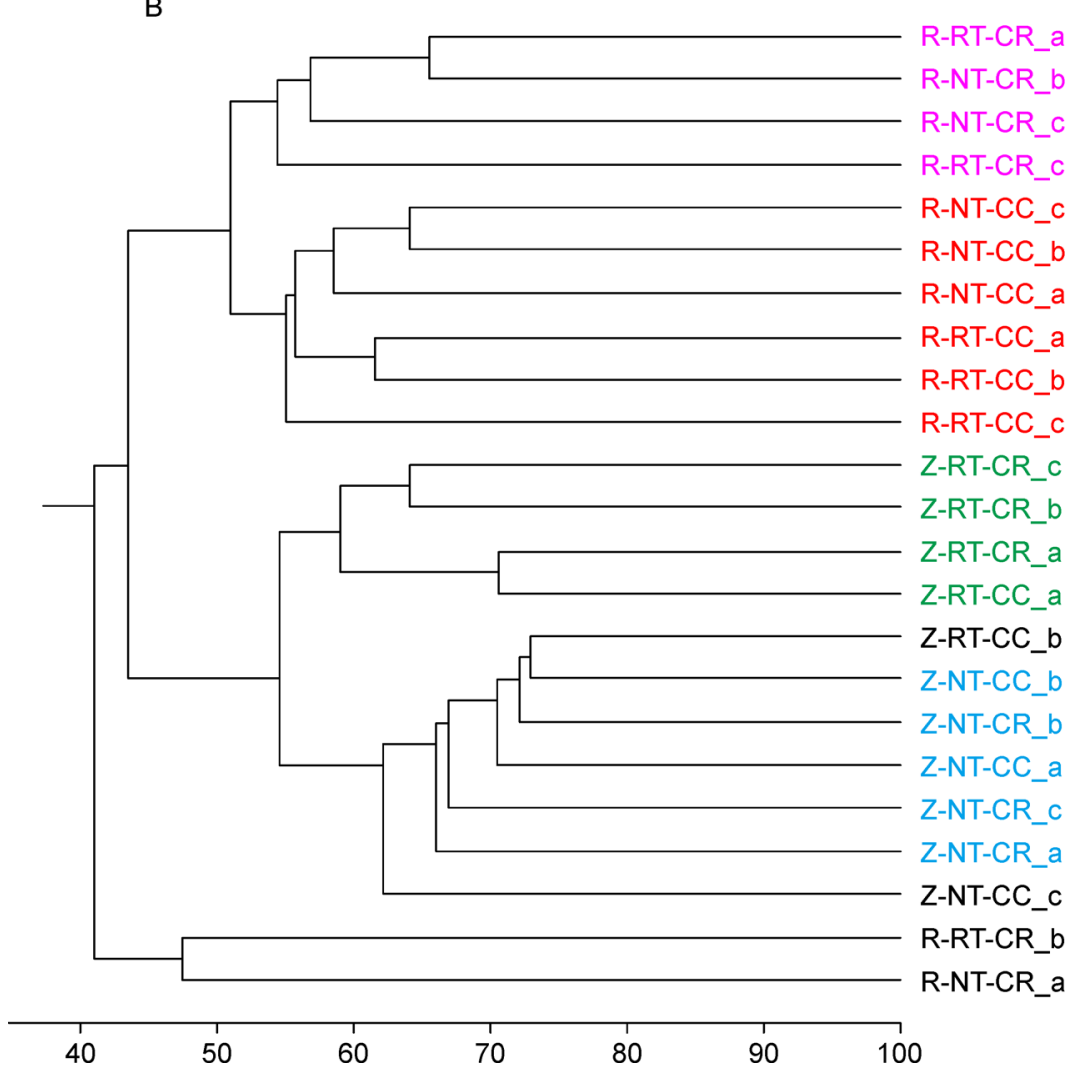

Fig. 3 A two-dimensional plot of the Principal Coordinate Analysis (PCoA) (A) and UPGMA (B) showing the clustering of bacterial communities among different agricultural practices. The first and second principal coordinates account for $43.5 \%$ and $14.1 \%$ of total variation respectively.

and root zone soils after 5-years of continuous agricultural practices are summarized in Tables 2 and 3 . Clearly, rhizosphere soils had higher mean $\mathrm{pH}$ values $(5.86 \pm 0.24)$, water content $\left(0.56 \pm 0.06 \mathrm{~g} \mathrm{~g}^{-1}\right)$, and available $\mathrm{P}(67.85 \pm$ $18.16 \mathrm{mg} \mathrm{kg}^{-1}$ ) than corresponding values of $5.49 \pm 0.16$, $0.24 \pm 0.01 \mathrm{~g} \mathrm{~g}^{-1}$ and $40.34 \pm 11.48 \mathrm{mg} \mathrm{kg}^{-1}$, respectively, for 
Table 2 The basic physicochemical properties of soil samples with various tillage methods in rhizosphere and root zone.

\begin{tabular}{|c|c|c|c|c|c|c|}
\hline $\begin{array}{l}\text { Soil } \\
\text { Zone }\end{array}$ & $\begin{array}{l}\text { Tillage } \\
\text { methods }\end{array}$ & $\begin{array}{l}\text { Crop } \\
\text { rotation }\end{array}$ & $\mathrm{pH}$ & $\begin{array}{l}\text { Water Content } \\
\left(\mathrm{g} \mathrm{g}^{-1}\right)\end{array}$ & $\begin{array}{l}\mathrm{OM} \\
\left(\mathrm{g} \mathrm{kg}^{-1}\right)\end{array}$ & $\begin{array}{l}\text { Total N } \\
\left(\mathrm{g} \mathrm{kg}^{-1}\right)\end{array}$ \\
\hline \multirow[t]{4}{*}{$\mathrm{R}$} & NT & $\mathrm{CC}$ & $5.48 \pm 0.20$ & $0.51 \pm 0.06$ & $24.43 \pm 6.46$ & $1.75 \pm 0.03$ \\
\hline & NT & $\mathrm{CR}$ & $5.86 \pm 0.06$ & $0.64 \pm 0.04$ & $20.18 \pm 1.73$ & $1.72 \pm 0.24$ \\
\hline & RT & $\mathrm{CC}$ & $5.98 \pm 0.14$ & $0.60 \pm 0.06$ & $19.70 \pm 4.03$ & $1.86 \pm 0.28$ \\
\hline & RT & $\mathrm{CR}$ & $6.12 \pm 0.05$ & $0.49 \pm 0.12$ & $22.15 \pm 0.51$ & $2.03 \pm 0.28$ \\
\hline \multirow[t]{4}{*}{ Z } & NT & $\mathrm{CC}$ & $5.72 \pm 0.10$ & $0.22 \pm 0.01$ & $18.88 \pm 1.26$ & $1.78 \pm 0.12$ \\
\hline & NT & $\mathrm{CR}$ & $5.56 \pm 0.26$ & $0.24 \pm 0.00$ & $18.45 \pm 1.33$ & $1.96 \pm 0.20$ \\
\hline & RT & $\mathrm{CC}$ & $5.41 \pm 0.21$ & $0.24 \pm 0.02$ & $16.71 \pm 2.86$ & $1.99 \pm 0.02$ \\
\hline & RT & $\mathrm{CR}$ & $5.27 \pm 0.03$ & $0.25 \pm 0.01$ & $23.92 \pm 1.20$ & $2.27 \pm 0.33$ \\
\hline $\begin{array}{l}\text { Soil } \\
\text { zone }\end{array}$ & $\begin{array}{l}\text { Tillage } \\
\text { methods }\end{array}$ & $\begin{array}{l}\text { Crop } \\
\text { rotation }\end{array}$ & $\begin{array}{l}\text { Total P } \\
\left(\mathrm{g} \mathrm{kg}^{-1}\right)\end{array}$ & $\begin{array}{l}\text { Available } \\
\mathrm{N}\left(\mathrm{mg} \mathrm{kg}^{-1}\right)\end{array}$ & $\begin{array}{l}\text { Available } \\
\mathrm{P}\left(\mathrm{mg} \mathrm{kg}^{-1}\right)\end{array}$ & $\begin{array}{l}\text { Available } \mathrm{K} \\
\left(\mathrm{mg} \mathrm{kg}^{-1}\right)\end{array}$ \\
\hline \multirow[t]{4}{*}{$\mathrm{R}$} & NT & $\mathrm{CC}$ & $0.63 \pm 0.11$ & $18.06 \pm 1.40$ & $73.12 \pm 9.71$ & $243.33 \pm 33.57$ \\
\hline & NT & $\mathrm{CR}$ & $0.56 \pm 0.10$ & $8.23 \pm 1.98$ & $39.36 \pm 8.30$ & $249.34 \pm 11.63$ \\
\hline & RT & $\mathrm{CC}$ & $0.56 \pm 0.17$ & $40.38 \pm 0.86$ & $89.72 \pm 12.24$ & $252.15 \pm 75.38$ \\
\hline & RT & $\mathrm{CR}$ & $0.56 \pm 0.14$ & $10.85 \pm 0.63$ & $69.18 \pm 19.27$ & $310.69 \pm 24.69$ \\
\hline \multirow[t]{4}{*}{ Z } & NT & $\mathrm{CC}$ & $0.60 \pm 0.07$ & $7.96 \pm 1.73$ & $45.12 \pm 13.44$ & $444.33 \pm 130.00$ \\
\hline & NT & $\mathrm{CR}$ & $0.62 \pm 0.08$ & $6.15 \pm 0.67$ & $56.95 \pm 2.82$ & $304.81 \pm 149.85$ \\
\hline & RT & $\mathrm{CC}$ & $0.47 \pm 0.05$ & $26.09 \pm 3.57$ & $29.65 \pm 9.55$ & $353.19 \pm 41.96$ \\
\hline & RT & $\mathrm{CR}$ & $0.59 \pm 0.21$ & $11.36 \pm 0.85$ & $29.65 \pm 16.60$ & $372.83 \pm 50.92$ \\
\hline
\end{tabular}

Note: No-tillage (NT), ridge tillage (RT), continuous cropping with corn (CC), and crop rotation with corn and bean (CR), rhizosphere (R) and root zone (Z).

root zone soils $(p<0.01)$, whereas available $\mathrm{K}$ in root zone soils $\left(368.79 \pm 50.15 \mathrm{mg} \mathrm{kg}^{-1}\right)$ was higher than rhizosphere soils $\left(263.88 \pm 27.21 \mathrm{mg} \mathrm{kg}^{-1}\right) \quad(p<0.01)$. RT significantly increased total $\mathrm{N}$ to $2.04 \pm 0.15 \mathrm{~g} \mathrm{~kg}^{-1}$, compare to $\mathrm{NT}$ $\left(1.80 \pm 0.09 \mathrm{~g} \mathrm{~kg}^{-1}, p<0.05\right)$ both in rhizosphere and root zone soils. CC treatment, compared to $\mathrm{CR}$, increased soil organic matter. Ridge tillage treatment $C R$ measured higher organic matter than $\mathrm{CC}$ both in rhizosphere and root zone soils. Meanwhile, available $\mathrm{N}$ accumulated in $\mathrm{CC}$ plot in rhizosphere soil $(p<0.05)$, as a result of root exudation, tissue exfoliation and therefore special microbial pattern (Langmeier et al., 2013). CC increased available $P$ in rhizosphere, but not in root zone soils $(p<0.01)$, with the average value of 81.42 and $54.27 \mathrm{~g} \mathrm{~kg}^{-1}$ in rhizosphere, and 37.39 and $43.30 \mathrm{~g} \mathrm{~kg}^{-1}$ in root zone soils under $\mathrm{CC}$ and $\mathrm{CR}$ treatments, respectively. Available $\mathrm{K}$ was significantly influenced by agricultural practices $(p<0.05)$. The higher values of available $\mathrm{K}$ in the root zone soils than rhizosphere soils were because of the higher absorption rate of $\mathrm{K}$ in the rhizosphere (Di Meo et al., 2003). Total $P$ in soil remained stable across all agriculture practices, and the lack of a significant correlation between agricultural practice and total $P$ is because the main driver for $P$ losses is soil erosion (Bechmann and Stålnacke, 2015).

3.4 The relationship between soil physicochemical properties and community composition

Redundancy analysis (RDA) was used to sort out the influences of different agricultural practices on soil bacterial communities within the context of eight measured soil physicochemical properties. Results (Fig. 4) show that the eight physicochemical variables contributed $45.4 \%$ of the bacterial community variation. The first and second axis accounted for $25.3 \%$ and $11.4 \%$ of total variation, respectively. The community structure represented by samples, was significantly related to available $\mathrm{N}, \mathrm{P}$, and $\mathrm{pH}$ by Permutation test $(p<0.05)$. Organic matter, $\mathrm{pH}$, available $\mathrm{P}$, and water content were positively affected by cropping systems in rhizosphere soil, while there was a strong negative correlation between those characteristics and bacterial community with tillage in root zone soils. Crop rotation with corn and bean, as compared with continuous corn cropping, increased soil $\mathrm{pH}$ 
Table 3 Multiple factor analysis of soil basic physicochemical properties with various tillage methods in rhizosphere and root zone.

\begin{tabular}{|c|c|c|c|c|c|c|c|c|}
\hline \multirow[t]{2}{*}{ Factors } & \multicolumn{2}{|l|}{$\mathrm{pH}$} & \multicolumn{2}{|c|}{ Water content } & \multicolumn{2}{|l|}{ OM } & \multicolumn{2}{|c|}{ Total N } \\
\hline & $\mathrm{F}$ & $p$-value & $\mathrm{F}$ & $p$-value & $\mathrm{F}$ & $P$-value & $\mathrm{F}$ & $p$-value \\
\hline NT/RT & 1.20 & 0.29 & 0.10 & 0.75 & 0.15 & 0.71 & 6.36 & $<0.05$ \\
\hline $\mathrm{CC} / \mathrm{CR}$ & 0.33 & 0.57 & 0.00 & 0.95 & 0.53 & 0.48 & 2.69 & 0.12 \\
\hline $\mathrm{R} / \mathrm{Z}$ & 34.27 & $<0.01$ & 153.75 & $<0.01$ & 2.22 & 0.16 & 2.94 & 0.11 \\
\hline NT/RT-CC/CR & 1.11 & 0.31 & 6.00 & $\leq 0.05$ & 7.62 & $\leq 0.05$ & 0.54 & 0.48 \\
\hline NT/RT-R/Z & 29.52 & $\leq 0.01$ & 1.11 & 0.75 & 1.65 & 0.22 & 0.07 & 0.79 \\
\hline $\mathrm{CC} / \mathrm{CR}-\mathrm{R} / \mathrm{Z}$ & 13.17 & $\leq 0.01$ & 0.00 & 0.95 & 2.75 & 0.12 & 0.75 & 0.40 \\
\hline NT/RT-CC/CR-R/Z & 1.11 & 0.31 & 4.43 & 0.05 & 0.03 & 0.86 & 0.06 & 0.81 \\
\hline \multirow[t]{2}{*}{ Factors } & \multicolumn{2}{|l|}{ Total P } & \multicolumn{2}{|c|}{ Available N } & \multicolumn{2}{|c|}{ Available P } & \multicolumn{2}{|c|}{ Available $\mathrm{K}$} \\
\hline & $\mathrm{F}$ & $p$-value & $\mathrm{F}$ & $p$-value & $\mathrm{F}$ & $p$-value & $\mathrm{F}$ & $p$-value \\
\hline NT/RT & 0.97 & 0.33 & 2.19 & 0.16 & 0.36 & 0.56 & 0.06 & 0.80 \\
\hline $\mathrm{CC} / \mathrm{CR}$ & 0.03 & 0.87 & 8.44 & $<0.05$ & 6.40 & $<0.05$ & 0.11 & 0.75 \\
\hline $\mathrm{R} / \mathrm{Z}$ & 0.00 & 0.97 & 3.24 & 0.09 & 23.43 & $<0.01$ & 9.21 & $<0.01$ \\
\hline NT/RT-CC/CR & 0.55 & 0.47 & 6.35 & $<0.05$ & 0.07 & 0.80 & 2.42 & 0.14 \\
\hline NT/RT-R/Z & 0.19 & 0.67 & 11.60 & $\leq 0.01$ & 17.85 & $\leq 0.01$ & 0.41 & 0.53 \\
\hline CC/CR-R/Z & 1.03 & 0.32 & 4.39 & 0.05 & 8.53 & $<0.05$ & 2.07 & 0.17 \\
\hline NT/RT-CC/CR-R/Z & 0.04 & 0.85 & 51.74 & $\leq 0.01$ & 1.39 & 0.26 & 0.60 & 0.45 \\
\hline
\end{tabular}

Note: Tillage method: NT or RT, Crop system: CC or CR, Location: R or Z. NT/RT, CC/CR, and R/Z represent the extent of communalities and discrepancies of the individual data set caused by a single factor; NT/RT-CC/CR, NT/RT-R/Z, and CC/CR-R/Z represent the extent of communalities and discrepancies of the individual data set caused by the interaction of two factors; NT/RT-CC/CR-R/Z represent the extent of communalities and discrepancies of the individual data set caused by the interaction of three factors.

value and decreased the available $P$, which could be attributed to the feedback of bacterial community distribution in rhizosphere soil. Nitrogen was not a limiting factor for community variation because increasing $\mathrm{N}$ did not increase the utilization of $\mathrm{N}$ in continuous corn cropping. The produced $\mathrm{N}$ by bean could be used for the corn growth next year with extended rotations of corn-bean (Stanger and Lauer, 2008). On the other hand, soil physicochemical variables including total $\mathrm{N}$, available $\mathrm{N}$, total $\mathrm{P}$, and available $\mathrm{K}$ could be used to indicate the community variation in root zone soils. Specifically, available $\mathrm{N}$, available $\mathrm{P}$, total $\mathrm{N}$, and total $\mathrm{P}$ were positively affected by tillage method in root zone soils. He et al. (2010) reported that ridge tillage was more effective in improving soil temperature and water use but disturbed the bacterial biodiversity more than no-tillage. However, no-tillage increased soil aggregation and therefore nutrient retention compared to disturbed ridge tillage (Jiao et. al., 2006).

The selected biomarkers response to different agricultural practices show how the interaction of bacteria and its surrounding physicochemical conditions affect community structure. Linear discriminant analysis coupled with effect size (LEfSe) was performed to identify bacterial taxa that significantly changed with agricultural practices. Non-parametric factorial Kruskal-Wallis (KW) sum-rank test and Wilcoxon rank-sum test were used to detect features with significantly different abundance and biological significance in the rhizosphere and root zone. The distinctly different bacterial taxa between the rhizosphere and root zone soils are shown in Fig. 5 and Fig. S3. More than 100 bacterial taxa were significantly more abundant in rhizosphere soils than those in root zone soils (Fig. S3). Explicitly, in the rhizosphere (Fig. 5A), Sphingomonadaceae, Fluciicola, Piellula and SHA_26 were significantly more abundant with crop rotation treatment, while Enterobacteriaceae, Microbacteriaceae, and Streptophyta were most abundant with the continuous cropping system $(p<0.05)$. Sphingomonadaceae are known for their ability for remediation in a wide range of biotechnological applications, which include antibiotic therapy of human disease (Ryan and Adley, 2010). On the other hand, in the root zone soils (Fig. 5B), several distinct bacterial taxa gathered with ridge tillage scenario, including Hyphomicrobiaceae, Turicibacter, Turicibacterales, and Turicibacteraceae, while Pirellulales were aggregated under no-tillage scenario $(p<0.05)$. Pirellulales are related to the functions of aerobic 


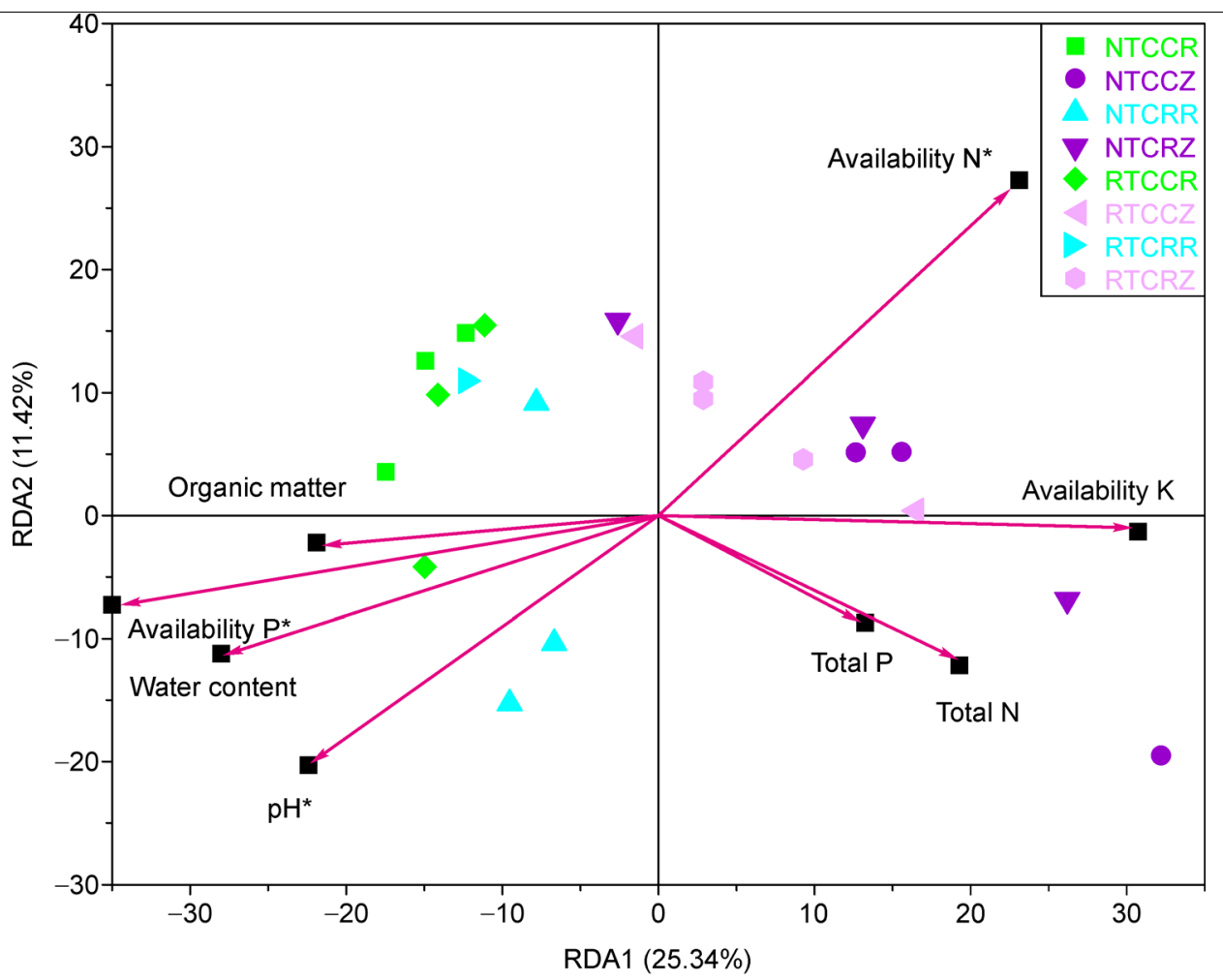

Fig. 4 The redundancy analysis (RDA) by R language (ggplot2) indicated the relationship between variation of soil bacterial communities and soil physicochemical properties. Note: The dots colored with green and light green represent CC and CR in rhizosphere, respectively, and the blue and purple represent NT and RT in root zone soils. The asterisk means the soil physicochemical properties was significant related to community structure, that is verified by the envfit function of the "Vegan" package in $\mathrm{R}(p<0.05)$.

A

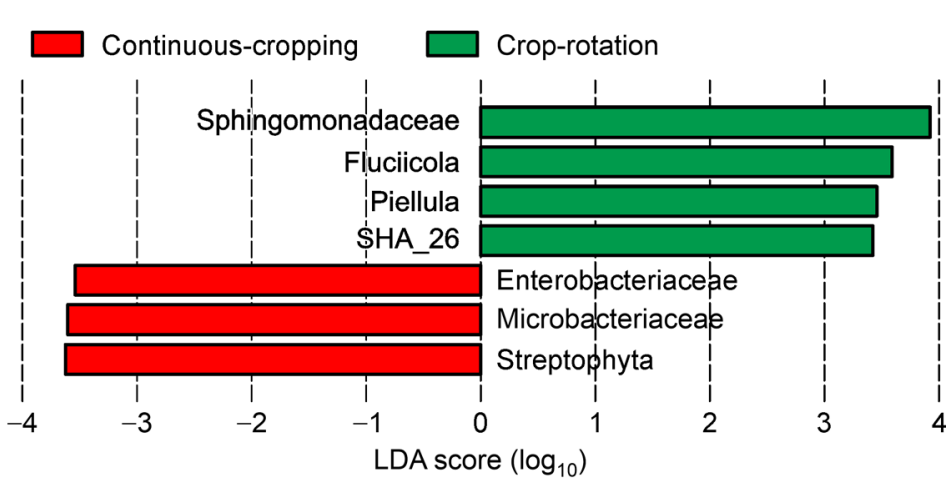

B

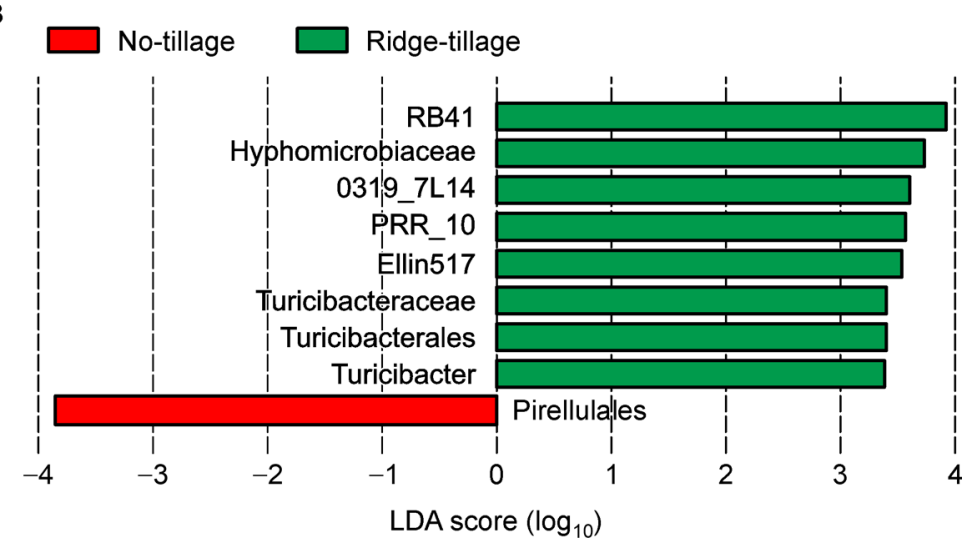

Fig. 5 The distinct taxa based on LEfSe analysis under different tillage practice (A) and crop rotation (B), respectively. 

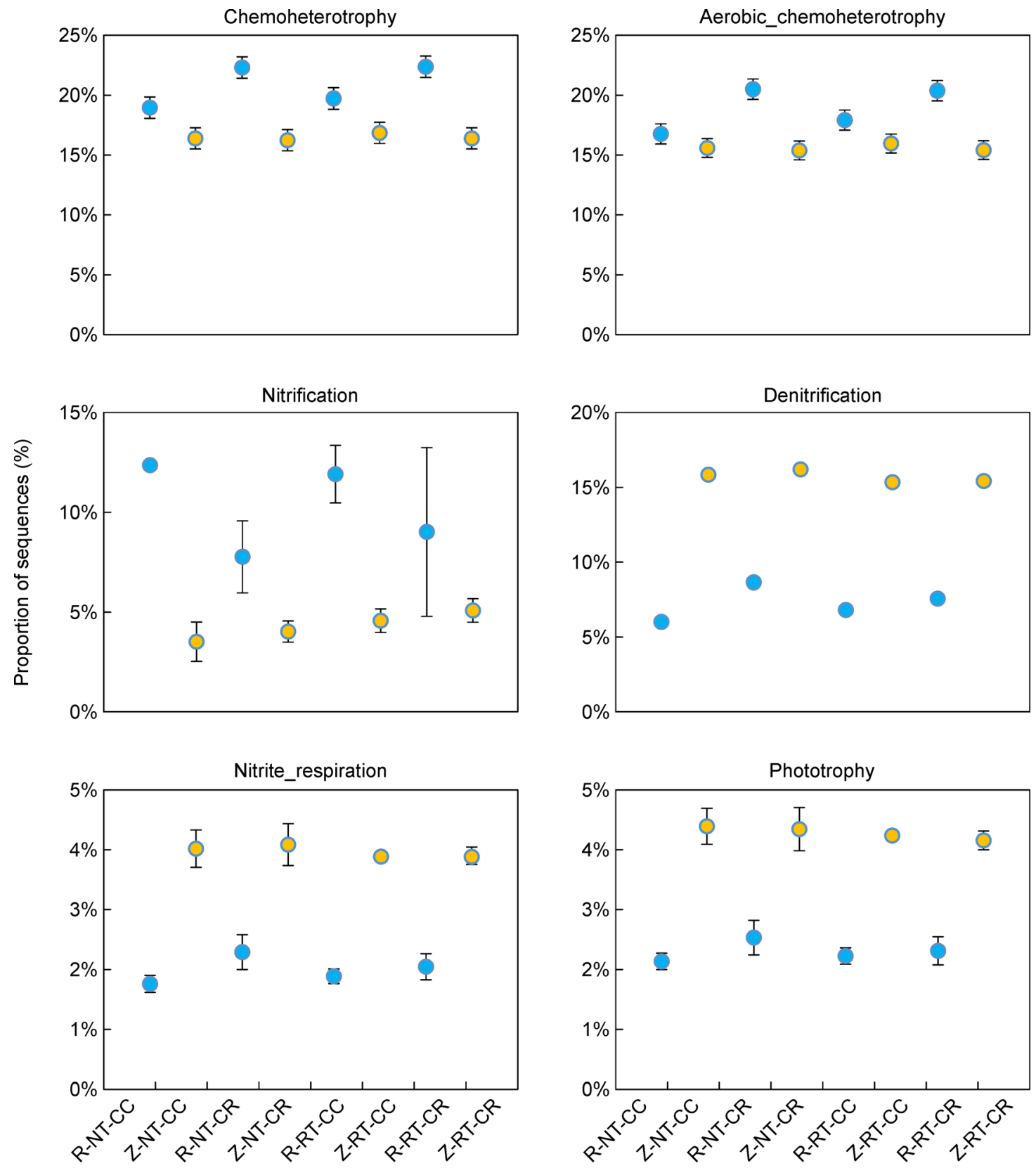

Fig. 6 Functional processes under different agricultural practices. The processes showing a proportion of genes with significant differences across agricultural practices are shown by FAPROTAX based on a database of cultured microorganisms.

ammonia-oxidation and ammonia cycle in the meadow ecosystem (Mohamed et al., 2009; Jiang et al., 2015). Turicibacter, an unknown new genus with a novel line of descent within the Gram-positive bacteria had a function on fermentative metabolism (Bosshard et al., 2002).

Functional profiles extrapolated and built from 16s rRNA gene sequences by the software of FAPROTAX demonstrate the process of metabolic activities in rhizosphere and root zone soils (Fig. 6). Genes related to chemoheterotrophy, aerobic_chemoheterotrophy, nitrification, denitrification, nitri- te_respiration, phototrophy and close to 14 marker genes had significant difference between different agricultural practice (Table 4). Six out of the 14 selected significantly processes are visualized in Fig. 6. In the rhizosphere, genes related to chemoheterotrophy, aerobic_chemoheterotrophy, nitrification had higher abundance than those genes in root zone soils. Root zone soils showed an enrichment in genes associated with denitrification, nitrite_respiration and phototrophy, which is in agreement with earlier results of selected biomarkers based on taxonomic microbial community. 
Table 4 Multiple factor analysis of domain functional communities with various tillage methods in rhizosphere and root zone.

\begin{tabular}{|c|c|c|c|c|c|c|c|c|c|c|}
\hline \multirow[t]{2}{*}{ Factors } & \multicolumn{2}{|c|}{$\begin{array}{l}\text { Chemohetero- } \\
\text { trophy }\end{array}$} & \multicolumn{2}{|c|}{$\begin{array}{l}\text { Aerobic_chemohe } \\
\text { terotrophy }\end{array}$} & \multicolumn{2}{|c|}{ Nitrification } & \multicolumn{2}{|c|}{$\begin{array}{l}\text { Aerobic_ammoni } \\
\text { a_oxidation }\end{array}$} & \multicolumn{2}{|c|}{$\begin{array}{l}\text { Nitrate_ } \\
\text { reduction }\end{array}$} \\
\hline & $\mathrm{F}$ & $p$-value & $\mathrm{F}$ & $p$-value & $\mathrm{F}$ & $p$-value & $\mathrm{F}$ & $p$-value & $\mathrm{F}$ & $p$-value \\
\hline NT/RT & 0.17 & 0.69 & 0.13 & 0.72 & 1.13 & 0.31 & 0.92 & 0.35 & 0.57 & 0.46 \\
\hline $\mathrm{CC} / \mathrm{CR}$ & 0.83 & 0.38 & 0.84 & 0.37 & 4.44 & 0.05 & 4.61 & $<0.05$ & 1.61 & 0.22 \\
\hline $\mathrm{R} / \mathrm{Z}$ & 10.92 & $<0.01$ & 5.71 & $<0.05$ & 38.70 & $<0.01$ & 40.12 & $<0.01$ & 0.00 & 0.95 \\
\hline NT/RT-CC/CR & 0.01 & 0.91 & 0.06 & 0.81 & 0.15 & 0.71 & 0.07 & 0.79 & 0.00 & 1.00 \\
\hline NT/RT-R/Z & 0.01 & 0.93 & 0.03 & 0.87 & 0.18 & 0.68 & 0.11 & 0.74 & 0.26 & 0.62 \\
\hline $\mathrm{CC} / \mathrm{CR}-\mathrm{R} / \mathrm{Z}$ & 1.49 & 0.24 & 1.53 & 0.24 & 5.24 & $<0.05$ & 5.40 & $<0.05$ & 1.97 & 0.18 \\
\hline NT/RT-CC/CR-R/Z & 0.01 & 0.94 & 0.03 & 0.87 & 0.20 & 0.66 & 0.17 & 0.68 & 0.18 & 0.68 \\
\hline \multirow[t]{2}{*}{ Factors } & \multicolumn{2}{|c|}{$\begin{array}{l}\text { Nitrate_- } \\
\text { respiration }\end{array}$} & \multicolumn{2}{|c|}{ Phototrophy } & \multicolumn{2}{|c|}{ Photoautotrophy } & \multicolumn{2}{|c|}{$\begin{array}{l}\text { Nitrite_ } \\
\text { respiration }\end{array}$} & \multicolumn{2}{|c|}{ Denitrification } \\
\hline & $\mathrm{F}$ & $p$-value & $\mathrm{F}$ & $p$-value & $\mathrm{F}$ & $p$-value & $\mathrm{F}$ & $p$-value & & \\
\hline NT/RT & 1.25 & 0.28 & 2.89 & 0.11 & 2.92 & 0.11 & 3.45 & 0.08 & 2.86 & 0.11 \\
\hline $\mathrm{CC} / \mathrm{CR}$ & 1.60 & 0.23 & 2.32 & 0.15 & 2.51 & 0.13 & 7.91 & $<0.01$ & 9.15 & $<0.01$ \\
\hline $\mathrm{R} / \mathrm{Z}$ & 3.73 & 0.07 & 260.87 & $<0.01$ & 275.76 & $<0.01$ & 350.66 & $<0.01$ & 363.52 & $<0.01$ \\
\hline NT/RT-CC/CR & 0.05 & 0.82 & 0.49 & 0.49 & 0.50 & 0.49 & 1.14 & 0.30 & 1.37 & 0.26 \\
\hline NT/RT-R/Z & 0.03 & 0.87 & 0.21 & 0.65 & 0.24 & 0.63 & 0.27 & 0.61 & 0.34 & 0.57 \\
\hline $\mathrm{CC} / \mathrm{CR}-\mathrm{R} / \mathrm{Z}$ & 1.99 & 0.18 & 1.61 & 0.22 & 1.67 & 0.22 & 2.33 & 0.15 & 2.88 & 0.11 \\
\hline NT/RT-CC/CR-R/Z & 0.16 & 0.70 & 0.29 & 0.60 & 0.38 & 0.55 & 0.52 & 0.48 & 0.77 & 0.39 \\
\hline
\end{tabular}

Note: Tillage method: NT or RT, Crop system: CC or CR, Location: R or Z. NT/RT, CC/CR, and R/Z represent the extent of communalities and discrepancies of the individual data set caused by a single factor; NT/RT-CC/CR, NT/RT-R/Z, and CC/CR-R/Z represent the extent of communalities and discrepancies of the individual data set caused by the interaction of two factors; NT/RT-CC/CR-R/Z represent the extent of communalities and discrepancies of the individual data set caused by the interaction of three factors.

Many studies have shown that microbial communities can acclimate to the changing environments over time (Wallenstein and Evans, 2011). The significant changes of functional bacteria observed in this study are likely the result of biological adaptation induced by agricultural practices. More research is needed to elucidate the specific nature of biological adaptation and acclimation, which will enable us to better choose optimal agricultural practices and can assist in developing strategies to constrain ecosystem response to global change and manage for preferential outcomes.

\section{Conclusion}

This study provided great opportunities for the systematic study of bacterial response to four agricultural practices. The results revealed significant differences in bacterial community structure between rhizosphere and root zone soil, were due to the crop rotation and tillage methods that the soils had undergone. Soil physicochemical interacted with bacterial communities and ultimately resulted in a clear community shifts when comparing bacterial communities from the root zone under no-tillage. Continuous cropping and crop rotation significantly distinguished in the rhizosphere soils. The bacterial diversity of rhizosphere soils was most affected by cropping methods with $\mathrm{pH}$, and available $\mathrm{P}$, while tillage methods regulated mainly bacterial species in the root zone soils through available $\mathrm{N}$. By picking and comparing the distinct biomarkers we found many of the bacterial taxa were previously recognized for their functional capabilities in nutrient cycling or metabolic processes. The significant difference of predictive genes in rhizosphere and root zone soils related to nutrient cycling or metabolic processes demonstrated that soil-plant interaction under different agricultural practices is important in shaping bacterial communities. It implies that agriculture practices alter soil physicochemical characteristics and influence the bacterial 
taxa, as well as their functions and activity. While bacterial community adaptations give strong feedbacks specifying the surrounding soil microbial niches.

\section{Abbreviations list}

$\begin{array}{ll}\text { LEfSe } & \begin{array}{l}\text { Linear discriminant analysis coupled } \\ \text { with effect size }\end{array} \\ \text { NT } & \text { No-tillage } \\ \text { RT } & \text { Ridge tillage } \\ \text { CC } & \text { Continuous corn cropping } \\ \text { CR } & \text { Crop rotation with corn and bean } \\ \text { R } & \text { Rhizosphere } \\ \text { Z } & \text { Root zone } \\ \text { PCoA } & \text { Principal coordinate analysis } \\ \text { LDA } & \text { Linear discriminant analysis } \\ \text { PCA } & \text { Principal component analysis } \\ \text { UPGMA } & \text { Unweighted pair-group method } \\ \text { RDA } & \text { with arithmetic means } \\ \text { N } & \text { Redundancy analysis } \\ \text { P } & \text { Nitrogen } \\ \text { C } & \text { Phosphorus } \\ \text { K } & \text { Carbon } \\ & \text { Potassium }\end{array}$

\section{Acknowledgments}

We acknowledge the financial support by the National Key Research and Development Program of China (2016YFD0200306) and the National Natural Science Foundation of China (41877412). The authors gratefully acknowledge the samples supported by Prof. Tusheng Ren from China Agricultural University.

\section{Electronic supplementary material}

Supplementary material is available in the online version of this article at https://doi.org/10.1007/s42832-020-0058-y and is accessible for authorized users.

\section{References}

Ai, C., Liang, G., Sun, J., Wang, X., He, P., Zhou, W., He, X., 2015. Reduced dependence of rhizosphere microbiome on plant-derived carbon in 32-year long-term inorganic and organic fertilized soils. Soil Biology \& Biochemistry 80, 70-78.

Albuquerque, J.P.D., Mota F.F.D., Weid, I.V.D., Seldin, L., 2006. Diversity of Paenibacillus durus strains isolated from soil and different plant rhizospheres evaluated by ARDRA and gyrB-RFLP analysis. European Journal of Soil Biology 42, 200-207.

Avidano, L., Gamalero, E., Cossa, G.P., Carraro, E., 2005. Characterization of soil health in an Italian polluted site by using microorganisms as bioindicators. Applied Soil Ecology 30, 21-33.

Bais, H.P., Weir, T.L., Perry, L.G., Gilroy, S., Vivanco, J.M., 2006. The role of root exudates in rhizosphere interactions with plants and other organisms. Annual Review of Plant Biology 57, 233-266.

Bao, S.D., 2000. Soil Agro-chemistry Analysis. 3rd ed. Beijing: China Agriculture Press, 56-58.

Bechmann, M., Stålnacke, P., 2005. Effect of policy-induced measures on suspended sediments and total phosphorus concentrations from three Norwegian agricultural catchments. Science of the Total Environment 344, 129-142.

Bing, H.E., Rui-Yu, L.I., Zhang, H., Dan-Wei, M.A., 2013. Effects of five alien Compositae plants on the growth of the microbial community of the rhizosphere and the soil's enzyme activity. Journal of Safety \& Environment 03, 176-180.

Bosshard, P.P., Zbinden, R., Altwegg, M., 2002. Turicibacter sanguinis gen. nov., sp. nov., a novel anaerobic, Gram-positive bacterium. International Journal of Systematic and Evolutionary Microbiology 52, 1263-1266.

Bradstreet, R.B., 1954. The Kjeldahl method for organic nitrogen. Analytical Chemistry 26, 185-187.

Chao, A., 1984. Non-parametric estimation of the number of classes in a population. Scandinavian Journal of Statistics 11, 265-270.

Di Meo, V., Michele, A., Paola, A., Pietro, V., 2003. Availability of potassium, calcium, magnesium, and sodium in 'bulk' and 'rhizosphere' soil of field-grown corn determined by electro-ultrafiltration. Journal of Plant Nutrition 26, 1149-1168.

Dogan, K., Celik, I., Gok, M., Coskan, A., 2011. Effect of different soil tillage methods on rhizobial nodulation, biomass and nitrogen content of second crop soybean. African Journal of Microbiological Research 5, 3186-3194.

Fan, K., Cardona, C., Li, Y., Shi, Y., Xiang, X., Shen, C., Wang, H., Gilbert, J.A., Chu, H., 2017. Rhizosphere-associated bacterial network structure and spatial distribution differ significantly from bulk soil in wheat crop fields. Soil Biology \& Biochemistry 113, 275-284.

Garbeva, P., van Veen, J.A., van Elsas, J.D., 2004. Microbial diversity in soil: selection of microbial populations by plant and soil type and implications for disease suppressiveness. Annual Review of Phytopathology 42, 243-270.

Gautheyrou. 2006. Handbook of Soil Analysis: Mineralogical, Organic and Inorganic Methods. Dordrecht: Springer, pp. 15-48.

Glöckner, F.O., Kube, M., Bauer, M., Teeling, H., Lombardot, T., Ludwig, W., Gade, D., Beck, A., Borzym, K., Heitmann, K., Rabus, R., Schlesner, H., Amann, R., Reinhardt, R., 2003. Complete genome sequence of the marine planctomycete Pirellula sp. strain 1. Proceedings of the National Academy of Sciences of the United States of America 100, 8298-8303.

Habig, J., Swanepoel, C., 2015. Effects of conservation agriculture and fertilization on soil microbial diversity and activity. Environments 2, 358-384.

He, J., Li, H., Kuhn, N.J., Wang, Q., Zhang, X., 2010. Effect of ridge tillage, no-tillage, and conventional tillage on soil temperature, water use, and crop performance in cold and semi-arid areas in 
northeast china. Australian Journal of Soil Research 48, 737-744.

$\mathrm{He}$, J., Li, J., Zheng, Y., 2013. Thoughts on the microbial diversitystability relationship in soil ecosystems. Shengwu Duoyangxing 21, 411-420.

Herman, M., 1990. Effect of tillage systems and crop sequence on the rhizosphere microflora of winter wheat. Soil \& Tillage Research 15 , 297-306.

Hooper, D.U., Chapin, F.S., Ewel, J.J., Hector, A., Inchausti, P., Lavorel, S., Naeem, S., Schmid, B., Setälä, H., Symstad, A.J., Vandermeer, J., Wardle, D.A., 2005. Effects of biodiversity on ecosystem functioning: A consensus of current knowledge. Ecological Monographs 75, 3-35.

Hu, C., Liu, G., Wu, Y., 2011. A review of soil microbial biomass and diversity measurements. Ecology \& Environmental Sciences 20, 1161-1167.

Huang, M., Chen, J., Cao, F., Jiang, L., Zou, Y., 2016. Rhizosphere processes associated with the poor nutrient uptake in no-tillage rice (Oryza sativa L.) at tillering stage. Soil \& Tillage Research 163, 10-13.

Hunter, P.R., Gaston, M.A., 1988. Numerical index of the discriminatory ability of typing systems: an application of Simpson's index of diversity. Journal of Clinical Microbiology 26, 2465-2466.

James, I.P., 2019. Exploring soil microbial communities: Opportunities for soil ecology research. Soil Ecology Letters 1, 1-2.

Jiang, Y.F., Ling, J., Dong, J.D., Chen, B., Zhang, Y.Y., Zhang, Y.Z., Wang, Y.S., 2015. Illumina-based analysis the microbial diversity associated with Thalassia hemprichii in Xincun Bay, South China Sea. Ecotoxicology (London, England) 24, 1548-1556.

Jiao, Y., Whalen, J.K., and Hendershot, W.H., 2006. No-tillage and manure applications increase aggregation and improve nutrient retention in a sandy-loam soil. Geoderma 134 (1-2):0-33.

Johansson, J.F., Paul, L.R., Finlay, R.D., 2004. Microbial interactions in the mycorrhizosphere and their significance for sustainable agriculture. FEMS Microbiology Ecology 48, 1-13.

Langmeier, M., Frossard, E., Kreuzer, M., Mäder, P., Dubois, D., Oberson, A., 2003. Nitrogen fertilizer value of cattle manure applied on soils originating from organic and conventional farming systems. Agronomie 22, 789-800.

Leff, J.W., Jones, S.E., Prober, S.M., Barberán, A., Borer, E.T., Firn, J. L., Harpole, W.S., Hobbie, S.E., Hofmockel, K.S., McCulley, R.L., La Pierre, K., Risch, A.C., Seabloom, E.M., Schütz, M., Steenbock, C., Stevens, C., Fierer, N., 2015. Consistent responses of soil microbial communities to elevated nutrient inputs in grasslands across the globe. Proceedings of the National Academy of Sciences of the United States of America 112, 10967-10972.

Liiri, M., Häsä, M.J., Haimi, J., Setälä, H., 2012. History of land-use intensity can modify the relationship between functional complexity of the soil fauna and soil ecosystem services-A microcosm study. Applied Soil Ecology 55, 53-61.

Lin, X., Hu, J., 2008. Scientific connotation and ecological service function of soil microbial diversity. Acta Pedologica Sinica 45, 892900.

Lindemann, S.R., Moran, J.J., Stegen, J.C., Renslow, R.S., Hutchison, J.R., Cole, J.K., Dohnalkova, A.C., Tremblay, J., Singh, K., Malfatti, S.A., Chen, F., Tringe, S.G., Beyenal, H., Fredrickson, J. K., 2013. The epsomitic phototrophic microbial mat of hot lake,
Washington: community structural responses to seasonal cycling. Frontiers in Microbiology 4, 323.

Lindsay, M.R., Lau, C.M., Tetteh, G., Snyder, L., Kieft, T.L., Lollar, B.S., Li, L., Maphanga, S., van Heerden, E., Onstott, T.C., 2012. Characterization of active members in $\mathrm{C}$ and $\mathrm{N}$ cycles in the subsurface environment of the Witwatersrand Basin. In: 2012 AGU Fall Meeting Abstracts. AGU Fall Meeting. American Geophysical Union. Abstract id. B43G-0499.

Mathew, R.P., Feng, Y., Githinji, L., Ankumah, R., Balkcom, K.S., 2012. Impact of no-tillage and conventional tillage systems on soil microbial communities. Applied and Environmental Soil Science 2012, 548620 .

Miura, T., Owada, K., Nishina, K., Utomo, M., Niswati, A., Kaneko, N., Fujie, K., 2016. The effects of nitrogen fertilizer on soil microbial communities under conventional and conservation agricultural managements in a tropical clay-rich Ultisol. Soil Science 181, 68 74.

Mohamed, N.M., Saito, K., Tal, Y., Hill, R.T., 2009. Diversity of aerobic and anaerobic ammonia-oxidizing bacteria in marine sponges. Multidisciplinary Journal of Microbial Ecology 4, 38-48.

Nannipieri, P., Ascher, J., Ceccherini, M.T., Landi, L., Pietramellara, G., Renella, G., Valori, F., 2008. Effects of root exudates in microbial diversity and activity in rhizosphere soils. Social Biology 15, 339-365.

Nicol, G.W., Christa, S., 2006. Ammonia-oxidising Crenarchaeota: important players in the nitrogen cycle? Trends in Microbiology 14 , 207-212.

Pielou, E.C., 1969. An Introduction to Mathematical Ecology. New York: Wiley Interscience.

Pierre, W.H., 1925. The H-ion concentration of soils as affected by carbonic acid and the soil-water ratio, and the nature of soil acidity as revealed by these studies. Soil Science 20, 285-305.

Prest, E.I., El-Chakhtoura, J., Hammes, F., Saikaly, P.E., van Loosdrecht, M.C.M., Vrouwenvelder, J.S., 2014. Combining flow cytometry and 16s rRNA gene pyrosequencing: A promising approach for drinking water monitoring and characterization. Water Resources 63, 179-189.

Rincon-Florez, V.A., Ng, C., Dang, Y.P., Schenk, P.M., Carvalhais, L. C., 2016. Short-term impact of an occasional tillage on microbial communities in a Vertosol after 43 years of no-tillage or conventional tillage. European Journal of Soil Biology 74, 3238.

Ryan, M.P., Adley, C.C., 2010. Sphingomonas paucimobilis: A persistent Gram-negative nosocomial infectious organism. Journal of Hospital Infection 75, 153-157.

Segata, N., Izard, J., Waldron, L., Gevers, D., Miropolsky, L., Garrett, W.S., Huttenhower, C., 2011. Metagenomic biomarker discovery and explanation. Genome Biology 12, R60.

Shanmugam V., Verma, R., Rajkumar, S., Naruka, D.S., 2011. Bacterial diversity and soil enzyme activity in diseased and disease-free apple rhizosphere soils. Annals of Microbiology 61, 765-772.

Signori, C.N., Thomas, F.O., Enrichprast, A., Pollery, R.C.G., Sievert, S.M., 2014. Microbial diversity and community structure across environmental gradients in Bransfield Strait, Western Antarctic Peninsula. Frontiers in Microbiology 5, 647-647. 
Srivastava, P., Singh, R., Tripathi, S., Singh, H., Raghubanshi, A.S. 2016. Soil carbon dynamics and climate change: Current agroenvironmental perspectives and future dimensions. Energy, Ecology \& Environment 1, 1-8.

Stanger, T.F., Lauer, J.G., 2008. Corn grain yield response to crop rotation and nitrogen over 35 years. Agronomy Journal 100, 643 650.

Sun, L., Pope, P.B., Eijsink, V.G.H., Schnurer, A., 2015. Characterization of microbial community structure during continuous anaerobic digestion of straw and cow manure. Microbial Biotechnology 8 , 815-827.

Tedersoo, L., Bahram, M., Põlme, S., Kõljalg, U., Yorou, N.S., Wijesundera, R., Ruiz, L.V., Vasco-Palacios, A.M., Thu, P.Q., Suija, A., Smith, M.E., Sharp, C., Saluveer, E., Saitta, A., Rosas, M., Riit, T., Ratkowsky, D., Pritsch, K., Põldmaa, K., Piepenbring, M., Phosri, C., Peterson, M., Parts, K., Pärtel, K., Otsing, E., Nouhra, E., Njouonkou, A.L., Nilsson, R.H., Morgado, L.N., Mayor, J., May, T.W., Majuakim, L., Lodge, D.J., Lee, S.S., Larsson, K.H., Kohout, P., Hosaka, K., Hiiesalu, I., Henkel, T.W., Harend, H., Guo, L., Greslebin, A., Grelet, G., Geml, J., Gates, G., Dunstan, W., Dunk, C., Drenkhan, R., Dearnaley, J., De Kesel, A., Dang, T., Chen, X., Buegger, F., Brearley, F.Q., Bonito, G., Anslan, S., Abell, S., Abarenkov, K., 2014. Global diversity and geography of soil fungi. Science 346, 1-11.

Teixeira, L.C., Peixoto, R.S., Cury, J.C., Sul, W.J., Pellizari, V.H. Tiedje, J., Rosado, A.S., 2010. Bacterial diversity in rhizosphere soil from Antarctic vascular plants of Admiralty Bay, maritime Antarctica. Multidisciplinary Journal of Microbial Ecology 4, 989
1001.

Venter, Z.S., Jacobs, K., Hawkins, H.J., 2016. The impact of crop rotation on soil microbial diversity: A meta-analysis. Pedobiologia 59, 215-223.

Wallenstein, M., Evans, S., 2011. Microbial adaptations to environmental change: a moving target for global change ecology. Nature Precedings https://doi.org/10.1038/npre.2011.5510.1.

Xu, J., Zhang, Y., Zhang, P., Trivedi, P., Riera, N., Wang, Y., Liu, X., Fan, G., Tang, J., Coletta-Filho, H.D., Cubero, J., Deng, X., Ancona, V., Lu, Z., Zhong, B., Roper, M.C., Capote, N., Catara, V., Pietersen, G., Vernière, C., Al-Sadi, A.M., Li, L., Yang, F., Xu, X., Wang, J., Yang, H., Jin, T., Wang, N., 2018. The structure and function of the global citrus rhizosphere microbiome. Nature Communications 9, 4894.

Zhang, C.B., Jin, Z.X., Li, J., 2001. Diversity of bacterial physiological groups and microbial flora in the soil of eight forest types of Tiantai Mountain, Zhejiang. Shengwu Duoyangxing 9, 382-388.

Zhang, X., Li, X., Zhang, C., Li, X., Zhang, H., 2011. Ecological risk of long-term chlorimuron-ethyl application to soil microbial community: An in-situ investigation in a continuously cropped soybean field in Northeast China. Environmental Science and Pollution Research International 18, 407-415.

Zhang, Z.Z., Zhang, Y., Chen, Z.M., 2010. Study on the soil microbial diversity of different forest types in Xiaolong Mountain. Pratacultural Science 27, 66-70.

Zhu, Y., 2020. Exploring the complex belowground world: soil ecologythe soil food webs and their ecological functions. Soil Ecology Letters 2, 1-1. 